\title{
SUPPORTING ECOLOGICAL INNOVATION AS A FACTOR FOR ECONOMIC DEVELOPMENT
}

\section{Erika Loučanová*}

Technical University in Zvolen, The Faculty of Wood Sciences and Technologies, Department of Marketing, Trade and World Forestry, Slovak Republic,e-mail: loucanova@tuzvo.sk

\section{Miriam Olšiaková}

Technical University in Zvolen, The Faculty of Wood Sciences and Technologies, Department of Marketing, Trade and World Forestry, Slovak Republic, e-mail: olsiakova@tuzvo.sk

\section{(Received: April 2019; Accepted: July 2019; Published: August 2019)}

\begin{abstract}
The paper deals with the evaluation of the ecological innovation as a factor for economic development through the correlation and regression analysis. The paper analysis the total ecological innovation index of Slovakia within the European Union and in relationship to growth GDP of Slovakia. Correlation and regression analysis examines the interdependence between total ecological innovation index and economic growth. GDP is one of the key elements of effective support for eco-innovation.
\end{abstract}

Keywords: innovation, ecological innovation, GDP, Slovakia.

JEL Codes: O31, O32

\section{Introduction}

The changes in the world economy are mainly due to the globalization of the world economy, and it is now almost impossible for the Slovak Republic to be successful without significant use of innovation. Nowadays, it is extremely important that a modern economy is based on knowledge and an innovative open society, as innovations that affect not only current life, but also future opportunities and conditions of life interfere in every activity in life.

At present, innovation is constantly increasing and emphasizing. Great emphasis is placed not only on innovation but also on sustainable development, especially on eco-innovation. Innovation effectiveness and efficiency of organizations depends

\footnotetext{
* Corresponding author: Erika Loučanová. E-mail: loucanova@tuzvo.sk
} $\underline{\text { use, distribution, and reproduction in any medium, provided the original author and source are credited. }}$ 
Loučanová, E., Olšiaková, M., (2019)

Supporting ecological innovation as a factor for economic development

on the ability of workers to create, design and implement innovation as well as many other factors. Therefore, the aim of this paper is to analyse the relation of ecological innovation performance in Slovakia and its GDP. Research on ecoinnovation is very actual, focusing on different areas of eco-innovation, but we do not know in this perception that it has been realized. The subject of research is the relationship between ecological innovation performance and Slovakia. Study limitations are only considering linear relationships, there may be variables other than $\mathrm{x}$ which are not studied, but they influence the response of the variable and a strong correlation does not imply cause and effect relationship.

The remainder of the paper is organized as follows: in the section 2 the literature review; section 3 methodology and empirical; section 4 empirical results to analyse the relationship of ecological innovation performance in Slovakia and its GDP and the last section presents the conclusions.

\section{Literature review}

The general objective of economic development in the new economy is to increase the quality of life of its population. The quality of life depends primarily on the performance of the economy, on the level of gross domestic product (GDP) and also on economic growth.

Economic growth represents "changes in the economy, which are reflected in an increase in basic macroeconomic variables over time." In the short term, this is an increase in real GDP, in the long run it is about potential product growth" (Lisý, 2011)

Liška et al. (2002) argues that economic growth is the growth of the country's ability to provide services and produce goods. A country can increase production by increasing resources or using existing factors more effectively.

According to Mankiw et al. (2009), economic growth is one of the main objectives of economic policy, resulting in an increase in the standard of the population and more diverse and better consumption. In particular, research, innovation, higher education and other factors are important factors for sustainable economic growth. At the same time, there is also a change in the subject of innovation. While in the past innovations were mainly related to products, in the services the innovative approach was minimal. At present, innovative development has been extended to all business activities, both internal and external, in both production and service (Hečková, 2007) and eco-innovations supporting sustainable economic growth (Loučanová et al., 2019; Straka, 2013; Štofková, 2013; Havierniková, 2012).

Eco-innovations can be used as a tool for companies to transform environmental constraints into opportunities for reduction or as a tool to get better reputation and advantage on the market. One of the most important interest of consumers is to 
Loučanová, E., Olšiaková, M., (2019)

Supporting ecological innovation as a factor for economic development

promote the performance of environmental product innovations, and to improve the realization of innovations (Carillo-Hermossilla et al., 2010).

Therefore, the Slovak National Strategy for Sustainable Development, as well as for support of eco-innovations as an approach of sustainable development. Ecoinnovations are involved with the main priorities not only in the Slovak Republic, but also in the EU and. OECD (Green Beings, 2015; Loučanová et al. 2019).

Eco-innovation is one of the objectives of the European Union (EU) elaborated in the Eco-Innovation Action Plan (EcoAP) and forms part of the economic policies (Hojnik and Ruzzier, 2016; Erygit and Özcüre, 2015). The scale of environmental problems as well as competitiveness challenges within the global economy has raised increasing awareness of the need to renew existing technological production and social behavioural patterns.

Eco-innovation has received a great amount of attention resulting in many efforts to analyze eco-innovation. Various studies emphasize that in order to better understand environmental implications eco-innovation needs to be studied at the relevant level taking into account wider effects of their application. The ECODRIVE study (CML et al. 2008, In Reid and Miedzinski, 2008) suggests that ecoinnovation should be analysed on different levels. At macro level Jo et al. (2015) evaluated and compared the eco-innovation performance level of European nations and Asian nations; Jang et al (2015) analyzed eco-innovation policies in Asian countries; Davidescu et al. (2015) evaluated Romanian eco-innovation performance and also identified the main eco-innovation poles at the European level (Observatory Scoreboard, Loučanová et al., 2015).

Eco-innovation globally emerged as an effort to implement sustainable development. States and companies established and implemented policies, strategies and action plans to achieve sustainable development. The issue of ecoinnovation at the level of European Union is formulated in the framework of Europe 2020, specifically in the "Innovation in the Union", documents of OECD, OSN a NSTUR (2014). Sustainable growth and the competitiveness of the EU should be in the future based on efficient use of resources, new eco-technologies and smart networks (European Commission, 2010).

Despite the wide-ranging discussion on eco-innovation, the concept of sustainable development does not refer to that issue as much as needed. The situation is similar in Slovakia.

\section{Methodology and empirical data}

Following the theoretical knowledge by analysis we have gained the necessary and relevant information related to the issue of innovation, eco-innovation (total ecoinnovation index) and GDP. The data are obtained from the database server Eurostat (2018) and European Commission, Environment, Eco-innovation Action

82 sciendo Studia Universitatis "Vasile Goldis" Arad. Economics Series Vol 29 Issue 3/2019 ISSN: 1584-2339; (online) ISSN: $2285-3065$

Web: publicatii.uvvg.ro/index.php/studiaeconomia. Pages $80-91$ 
Loučanová, E., Olšiaková, M., (2019)

Supporting ecological innovation as a factor for economic development

Plan, The Eco-Innovation Scoreboard and the Eco-Innovation Index (2018). Indicators relevant to the analysis of parameters of ecological innovation and GDP are sorted by selection of examined indicators. Subsequently, the study of dependencies between total ecological innovation index and the growth of gross domestic product is realized through correlation and regression analysis.

"With regression we analyse the relationship among variables. The dependent variable is denoted $\mathrm{Y}$, the independent variable $\mathrm{X}$. The variables will never be perfectly related, so there is always an error term. Variation from the regression line can be thought of as having two parts: explained variation, which is accounted for by the independent variable, and unexplained variation, which is unaccounted for by the independent variable. That is, part of the change in a variable is due to another variable that we hypothesize, and part is due to other factors.

In regression analysis we are concerned with whether the relationship pattern between two values of variables can be described as a straight line, which is the simplest and most commonly used form.

$$
Y=a+b X
$$

where: $\mathrm{Y}$ is the dependent variable, measured in units of the dependent variable, $\mathrm{X}$ is the independent variable, measured in units of the independent variable, and a and $b$ are constants defining the nature of the relationship between the variables $X$ and $\mathrm{Y}$.

a or Y-intercept (also known as Yint) is the value of $\mathrm{Y}$ when $\mathrm{X}=0$.

$\mathrm{b}$ is the slope of the line and it is known as the regression coefficient and it is the change in $\mathrm{Y}$ associated with a one-unit change in $\mathrm{X}$.

The greater the slope or regression coefficient, the more influence the independent variable has on the dependent variable, and the more change in $\mathrm{Y}$ associated with a change in $X$.

The regression coefficient is typically more important than the intercept from a policy researcher perspective as we are usually interested in the effect of one variable on another" (Regression Analysis, 2019).

"Because visual examinations are largely subjective, we need a more precise and objective measure to define the correlation between the two variables. To quantify the strength and direction of the relationship between two variables, we use the linear correlation coefficient:

$$
r=\frac{\sum \frac{\left(x_{i}-\bar{x}\right)\left(y_{i}-y\right)}{s_{x} s_{y}}}{n-1}
$$

Where: $\bar{x}$ and $s_{x}$ are the sample mean and sample standard deviation of the $x$ 's, and $\bar{y}$ and $s_{\mathrm{y}}$ are the mean and standard deviation of the y's, $\mathrm{n}$ is the sample size is. 
Loučanová, E., Olšiaková, M., (2019)

Supporting ecological innovation as a factor for economic development

This statistic numerically describes how strong the straight-line or linear relationship is between the two variables and the direction, positive or negative.

In ANOVA, we partitioned the variation using sums of squares so we could identify a treatment effect opposed to random variation that occurred in our data.

The sums of squares and mean sums of squares are typically presented in the regression analysis of variance table. The ratio of the mean sums of squares for the regression and mean sums of squares for error form an F-test statistic used to test the regression model.

The relationship between these sums of square is defined as

Total Variation $=$ Explained Variation + Unexplained Variation

The larger the explained variation, the better the model is at prediction. The larger the unexplained variation, the worse the model is at prediction. A quantitative measure of the explanatory power of a model is $\mathrm{R}^{2}$, the Coefficient of Determination:

$$
R^{2}=\frac{\text { Explained Vatiation }}{\text { Total Variation }}
$$

The Coefficient of Determination measures the percent variation in the response variable (y) that is explained by the model. Values range from 0 to 1 . An $R^{2}$ close to zero indicates a model with very little explanatory power. An $\mathrm{R}^{2}$ close to one indicates a model with more explanatory power" (Kiernan, D., 2007).

In conclusion, the inductive-deductive method summarizes the facts and facts found and generates general conclusions based on the facts of the previous analyses.

\section{Empirical results}

Slovakia, regarding the valuation of the performance in the area of eco-innovation in 2018, belongs to the group of economies whose eco-innovation index does not reach high level (Figure 1). The best-rated countries are Sweden, Finland, Germany and Luxemburg. Slovakia is the eighth country nearly with the lowest value of ecoinnovation index. 
Loučanová, E., Olšiaková, M., (2019)

Supporting ecological innovation as a factor for economic development

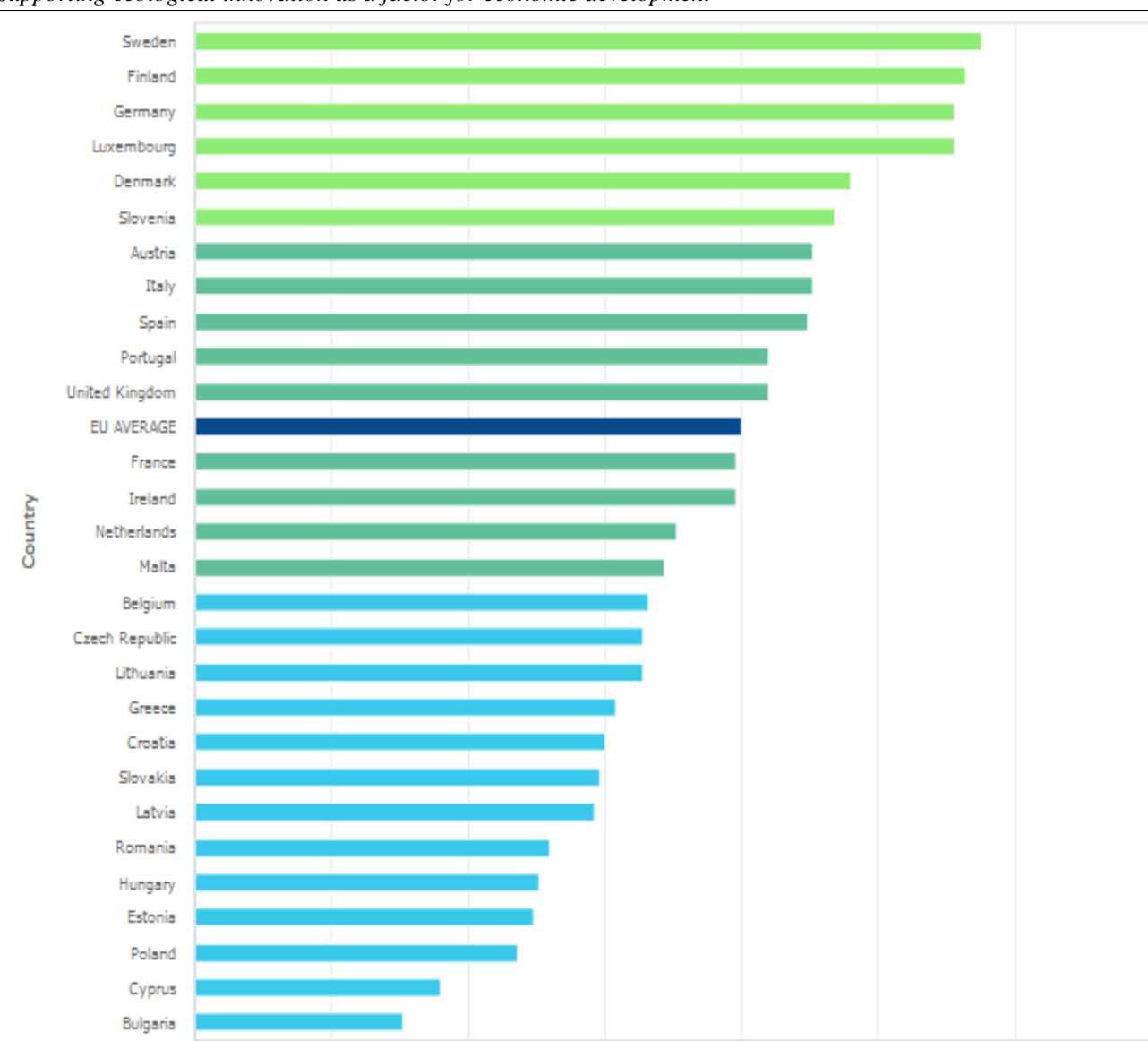

Performance groups

Eco-l Leader Average Eco-I performers Countries catching up with Eco-I

Figure 1 Eco-innovation performance of the EU Members States

Source: European Commission, Environment, Eco-innovation Action Plan, The EcoInnovation Scoreboard and the Eco-Innovation Index (2019)

Based on the data from Eurostat (2018) and the European Commission, Environment, Eco-Innovation Action Plan, The Eco-Innovation Scoreboard and the Eco-Innovation Index (2018), we made the correlation and regression analysis of the dependence between total ecological innovation index and GDP to Slovakia, Table 1.

$S$ sciendo Studia Universitatis "Vasile Goldis" Arad. Economics Series Vol 29 Issue 3/2019 
Loučanová, E., Olšiaková, M., (2019)

Supporting ecological innovation as a factor for economic development

\section{Table 1 Results of statistical evaluation}

\section{SUMMARY OUTPUT}

\begin{tabular}{lc}
\hline \multicolumn{2}{c}{ Regression Statistics } \\
\hline Multiple R & 0,867403 \\
R Square & 0,752388 \\
Adjusted R Square & 0,690485 \\
Standard Error & 7,768217 \\
Observations & 6 \\
\hline
\end{tabular}

ANOVA

\begin{tabular}{lccccc}
\hline & $d f$ & $S S$ & $M S$ & $F$ & $\begin{array}{c}\text { Significance } \\
\text { Regression }\end{array}$ \\
\hline Residual & 1 & 733,4526 & 733,4526 & 12,15428 & 0,025207 \\
Total & 4 & 241,3808 & 60,34519 & & \\
\hline
\end{tabular}

\begin{tabular}{lrrrrrr}
\hline & Coefficients & $\begin{array}{c}\text { Standard } \\
\text { Error }\end{array}$ & t Stat & P-value & $\begin{array}{c}\text { Lower } \\
95 \%\end{array}$ & $\begin{array}{c}\text { Upper } \\
95 \%\end{array}$ \\
\hline Intercept & $-144,883$ & 59,18773 & $-2,44786$ & 0,070608 & $-309,215$ & 19,44842 \\
$\begin{array}{l}\text { Total Eco- } \\
\text { innovation }\end{array}$ & 2,640535 & 0,757403 & 3,486299 & 0,025207 & 0,537646 & 4,743424 \\
Index & & & & & & \\
\hline
\end{tabular}

Source: authors' computation

The result of the correlation analysis is the first part of the regression statistics output. The value of the correlation coefficient is 0.867403 . The closer this value is to 1 , the stronger the dependence is. In our case it is a high degree of tightness of the relation between GDP and ecological innovations in Slovakia. The value of RSquare is the value of the determination coefficient and in our case it is the value of 0.752388 . This multiplication value of 100 indicates that the selected regression line explains the variability in average GDP growth to about $75 \%$. The other represents unexplained variability, the impact of random factors, and other

86 Studia Universitatis "Vasile Goldis" Arad. Economics Series Vol 29 Issue 3/2019 ISSN: 1584-2339; (online) ISSN: $2285-3065$

Web: publicatii.uvvg.ro/index.php/studiaeconomia. Pages 80-91 
Loučanová, E., Olšiaková, M., (2019)

Supporting ecological innovation as a factor for economic development

unspecified effects. Adjusted R-square also takes into account the number of estimated parameters and the number of measurements. The Standard Error should be as small as possible. The analysis of the dependence between GDP and ecological innovations was carried out for Slovakia. In the ANOVA section, we are testing a null hypothesis that argues that the model we have chosen to explain dependency, is not appropriate (an alternative hypothesis claims the opposite). The $\mathrm{F}$ test is used to evaluate this claim. Significance $F=0.025207<0,05(\alpha-$ significance level). It means we reject $\mathrm{H} 0$, which means that the model has been chosen correctly and therefore average GDP growth is dependent on ecoinnovations.

We find out whether there is dependence between eco-innovation and average GDP growth. The output of the regression analysis points to the fact that Interceptb0 equals $-144,883$. We can state: If the eco-innovation index were zero, the average GDP growth would be $-144,883$ euros. In the index of eco-innovation in relation to average GDP growth, $\mathrm{X}$ Variable is 2.640535 , which means that if average GDP growth increases by $1 \%$, the eco-innovation index will increase by almost 3 points. This claim is statistically significant on the basis of the $p$-value for the ecological index and average GDP growth, as its value is less than 0.05 (0.025207). In addition to this information, this part of the output table also offers a 95\% confidence interval for $\mathrm{b} 0$ and $\mathrm{b} 1$. If the average GDP growth increases by $1 \%$, the total ecological index with $95 \%$ probability increases in the range from 0.537646 to 4.743424 points.

\section{Discussion}

Our findings also confirm the theoretical basis. As Lisý (2011) states that economic growth represents changes in the economy, which are reflected in an increase in basic macroeconomic variables over time, which has confirmed that there is indeed a dependence between the observed parameters of average GDP growth and ecological innovation index.

These results are also confirmed by Mankiw et al. (2009). He argues that research, innovation (i.e., eco-innovation) and other elements are major factors in sustainable economic growth.

As stated by the Office of the Government of the Slovak Republic (2015), Slovakia, within the support of research and development as a factor of sustainable economic development, should focus on its development of strong stands in this area, eliminating weaknesses and threats, opportunities that open up for Slovak science.

These results show that Slovakia needs to increase its R\&D support for sustainable economic growth. Konôpka (2011) states that quality research and development is the basis for sustainable development of society. Therefore it is natural to focus on: 
Loučanová, E., Olšiaková, M., (2019)

Supporting ecological innovation as a factor for economic development

effective and ethical system of support for research and development as a factor of important elements of ensuring sustainable economic growth and development of society, competitiveness of the economy and quality of life of Slovak citizens, reflecting on the intentions of effective and ethical principles of the R\&D support system; a functioning system of technology and knowledge transfer from research and development to practice; The Slovak Republic as part of the European Research Area; a constantly evolving system of scientific and technological cooperation; as well as the company's increasing interest in R\&D and the results achieved.

As part of these findings, we recommend supporting the creation of innovation and eco-innovations in R\&D, according to the European Commission's strategy, so that science and research will develop a smart, sustainable and inclusive economy delivering high levels of employment, productivity and social cohesion. In the case of Slovakia, it is necessary to take into account the needs of Slovak science, its starting points and national specifics, in order to support growth of the EU, as Marlier (2010) states. It should focus on increasing spending on science and research in the Slovak Republic, as these are dependent on GDP growth. Science and research development should support projects focusing on industrial innovation, including investments in key technologies, greater access to capital, as well as support for SMEs, to address major social challenges, focusing mainly on eco-innovation in the area of climate change, sustainable transport, renewable energy.

Another recommendation is that science and research funding should focus on increasing business finance, which should amount to $2 / 3$ of the total funding for science and research, as stated in the Lisbon Strategy, which Slovakia does not meet.

The research presented on the basis of these analyses provides both theoretical and practical information for innovator, business and politicians in the area of ecological innovation and growth GDP. The acquisition of theoretical knowledge can then lead to setting objectives and policies to their real implementation in practice and help to increasing the ecological innovation in Slovakia in the context of innovation and environmental processes, as stated by several authors, e.g. Ipate et al. (2015) and others.

\section{Conclusions}

Based on the analyzes, we found that the Slovak Republic is among the countries with a low ecological innovation index in the European Union. Taking into account the results from implemented regression and correlation analysis of total ecological innovation index and GDP; GDP is one of the key elements of effective support for eco-innovation. With regard to their potential consequences and environmental

88 Sciendo Studia Universitatis "Vasile Goldis" Arad. Economics Series Vol 29 Issue 3/2019 ISSN: 1584-2339; (online) ISSN: 2285 - 3065

Web: publicatii.uvvg.ro/index.php/studiaeconomia. Pages 80-91 
Loučanová, E., Olšiaková, M., (2019)

Supporting ecological innovation as a factor for economic development

processes, it also supports the sustainable economic development of Slovakia. In consideration of the low value of the eco-innovation index in Slovakia and the existing dependency between GDP and the eco-innovation index, it would be advisable to increase support for $R \& D$ as a factor for sustainable economic development and thereby to support the strengths and eliminate weaknesses and threats and as well as to use the opportunities that open up within the issue related to eco-innovation for Slovak science.

\section{Acknowledgements}

The authors thank the anonymous reviewers and editor for their valuable contribution.

\section{Funding}

This research was funded by Scientific Grant Agency of the Ministry of Education, Science, Research and Sport of the Slovak Republic and the Slovak Academy of Sciences, grant number 1/0674/19, "Proposal of a model for the eco-innovation integration into the innovation process of companies in Slovakia in order to increase their performance".

\section{Author's Contributions}

Erika Loučanová elaborated article and Miriam Olšiaková has made a correction of English language.

\section{Disclosure Statement}

The authors declare no conflict of interest.

\section{References}

1. Carrillo-Hermosilla J., del González P.R., Könnölä T. (2009), What is ecoinnovation?, Eco-Innovation, Palgrave Macmillan, London.

2. Davidescu, A.A.M., Vass Paul, A.M., Gogonea, R.M., Zaharia, M., (2015), Evaluating Romanian Eco-Innovation Performances in European Context, Sustainability 2015, 7(9), pp. 12723-12757.

3. ECOAP, (2018), Akčný plán pre environmentálne technológie. [on-line], www.enviroportal.sk [cit. 21.03.2018], Available from:

https://www.enviroportal.sk/environmentalne-temy/starostlivost-o-zp/dobrovolnenastroje-environmentalnej-politiky/environmentalne-technologie;

http://old.sazp.sk/public/index/go.php?id=1914

4. Erygit, N., Özcüre, G., (2015), Eco-Innovation as Modern Era Strategy of Companies in Developing Countries: Comparison Between Turkey and European Union, Procedia - Social and Behavioral Sciences, B.m.: Elsevier, 3.7., 195, s. $1216-1225$. 
Loučanová, E., Olšiaková, M., (2019)

Supporting ecological innovation as a factor for economic development

5. European Commision, (2010), Európa 2020 - Stratégia na zabezpečenie inteligentného, udržatel'ného a inkluzívneho rastu. Brusel: Európska komisia. [online], [cit. 20.01.2018], Available from:

http://eur-lex.europa.eu/LexUriServ/LexUriServ.

do?uri=COM:2010:2020:FIN:SK:PDF.

6. European Commission, Environment, Eco-innovation Action Plan, The EcoInnovation Scoreboard and the Eco-Innovation Index (2018) [online] [cit. 20.12.2018], Available from:

https://ec.europa.eu/environment/ecoap/indicators/index_en

7. Eurostat (2018) [online] [cit. 20.12.2018] Available from:

https://ec.europa.eu/eurostat

8. Green Beings, (2015), Eco Innovations - how eco ideas become a reality. (n.d.). [online] [cit. 10.03.2015] Available from: http://www.greenbeings.com.au/tips/ecoinnovations.aspx

9. Havierniková, K., (2012), Selected aspects of clusters initiatives in the field of industry in the Slovak Republic, In Proceedings of 21st International Conference on Metallurgy and Materials (METAL 2012) (pp. 1838-1845).

10. Hečková, J., (2007), Rozvoj v oblasti technológií a inovácií ako determinant ekonomického rozvoja krajiny. [online]. [cit. 2018-03-25], Available from:< https://is.muni.cz/do/1456/soubory/aktivity/obzor/6182612/7667728/02Heckova.pd f>.

11. Hojnik, J., Ruzzier. M., (2016), What drives eco-innovation? A review of an emerging literature, Environmental Innovation and Societal Transitions [online], B.m.: Elsevier, 1.6., 19, s. 31-41.

12. Ipate, N., David, K.G., Ipate, I., Bogdan, A., (2015), The bioeconomy model in future sustainable development, Studia Universitatis "Vasile Goldiş" Arad, Economics Series 25(2).

13. Jang, E.K., Park, M.S., Roh, T.W., Han, K.J., (2015), Policy Instruments for Eco-Innovation in Asian Countries, Sustainability 2015, 7(9).

14. Jo, J.H., Roh, T.W., Kim, S., Youn, Y.CH., Park, M.S., Han, K.J., Jang, E.K., (2015), Eco-Innovation for Sustainability: Evidence from 49 Countries in Asia and Europe, Sustainability 2015, 7(12).

15. Kiernan, D., (2007), Natural Resources Biometrics, SUNY College of Environmental Science and Forestry, New York.

16. Konôpka J., (2011), Science and research - basic source of knowledge and innovation incentives, Lesn. Čas. - Forestry Journal, 57 (1): 1-10, 2 fig., ref. 14, ISSN 0323 - 1046.

17. Liška, V., Frait, J., Gazda, J., Macháček, M., Spáčilová, L., Tomadzič, I., Varadzin, F., (2002), Makroekonomie, Praha: Professional Publishing.

90 S sciendo Studia Universitatis "Vasile Goldis" Arad. Economics Series Vol 29 Issue 3/2019 ISSN: 1584-2339; (online) ISSN: 2285 - 3065

Web: publicatii.uvvg.ro/index.php/studiaeconomia. Pages $80-91$ 
Loučanová, E., Olšiaková, M., (2019)

Supporting ecological innovation as a factor for economic development

18. Lisý, J. et al., (2011), Ekonómia, Bratislava : Iura Edition, 2011.

19. Loučanová, E., Parobek, J., Kalamárová, M., Paluš, H., Lenoch, J, (2015), Ecoinnovation performance of Slovakia, Procedia Economics and Finance 26, pp. 920924.

20. Loučanová, E., Parobek, J., Nosálová, M., \& Dopico, A., (2019), The Perception of Respondents of Intelligent Packaging in Slovakia as Ecological Innovations, Studia Universitatis „Vasile Goldiş” Arad, Economic Series, 29(1), pp. 58-67.

21. Mankiw, N.G., Weinzierl M., Yagan, D., (2009), "Optimal Taxation in Theory and Practice", Journal of Economic Perspectives, 23 (4): 147-174.

22. Marlier, E. et al., (2010), Europe 2020: Towards a more social EU? [online] 2010, [cit. 2018-02-19], Available from:

<https://books.google.sk/books?hl=sk\&lr=\&id=YipIKAwcSeYC\&oi=fnd\&pg=PA $11 \& d q=$ strategy+europe $+2020 \&$ ots $=$ UL-

XFGNmZ6\&sig=hzIV771SQ30uXAZLKjuetevFHeE\&redir_esc=y\#v=onepage\&q $=$ strategy\%20europe $\% 202020 \& \mathrm{f}=$ false $>$.

23. OECD, (2005), Oslo manual guidelines for collecting and interpreting innovation data, Organisation for Economic Co-operation and Development: Statistical Office of the European Communities, Paris.

24. Regression Analysis, (2019), [online]. [cit. 2019-06-205], Available from: $<$ courses.washington.edu/urbdp520/UDP520/regression.doc

25. Reid, A., Miedzinski, M., (2008), Eco-innovation - final report for sectorial innovation watch.

26. Štofková, K., (2013), Sietové podnikanie. Manažment a sietové podnikanie vo vedomostnej ekonomike. Žilinská univerzita v Žiline, EDIS-vydavatel'stvo ŽU v Žiline.

27. Straka, M., (2013), Logistika distribúcie, Ako efektívne dostat' výrobok na trh. EPOS, Bratislava. 